\title{
PHOSPHATASES IN TESTES AND EPIDIDYMIDES OF ALBINO RATS AFTER PARTIAL BODY $\gamma$-IRRADIATION
}

\author{
G. S. GUPTA AND S. R. BAWA \\ Department of Biophysics, Panjab University, Chandigarh, India \\ (Received 23rd March 1971, revised 26th Fuly 1971)
}

Our knowledge of the effects of ionizing radiation on the biochemical processes of testes and epididymides is meagre. Enzymatic studies of reproductive organs have been described (Ito, 1966; Gupta \& Bawa, 1969), but the immediate effect of radiation in cell injury has been related to the curtailment of biosyntheses of nucleic acids and alterations in their chemical configuration. The events preceding the decrease of nucleic acid syntheses and other metabolic processes during irradiation are not understood. This communication describes the effects of localized $\gamma$-irradiation on phosphatases and their probable rôle in the regulatory mechanisms in the testes and epididymides.

Thirty, normal, white albino rats, weighing 140 to $200 \mathrm{~g}$, were separated to form seven groups, consisting of four to five rats in each group. Rats were irradiated at a single surface dose of $2000 \mathrm{R}$ from a cobalt- 60 source shielded in a Theratron radiotherapy unit. The rats were anaesthetized by Nembutal and the scrotum was irradiated ( 70 to $80 \mathrm{R} / \mathrm{min}$ ) at a distance of $65 \mathrm{~cm}$ from the source. Twenty-five sham irradiated animals acted as controls. The animals were decapitated at various intervals from $24 \mathrm{hr}$ to 26 days after irradiation. The tissues from a group of animals were pooled, frozen, cut into pieces and randomized. About $1 \mathrm{~g}$ of the tissue was homogenized to give a 5 to $10 \%$ aqueous homogenate for enzyme assays. The method for acid phosphatase and inorganic phosphate have been described earlier (Gupta \& Bawa, 1970). Alkaline $\beta$-glycerophosphatase was determined at $\mathrm{pH} 8 \cdot 6$ (veronal buffer); other conditions being similar to the acid phosphatase assay. Inorganic pyrophosphatase was determined by hydrolysing $0.042 \mathrm{M}$-sodium pyrophosphate by $0.1 \mathrm{ml}$ enzyme at $\mathrm{pH} 8.4$ (tris buffer, $0.1 \mathrm{M}$ ) using magnesium as activator for $15 \mathrm{~min}$ at $37^{\circ} \mathrm{C}$. Adenosine triphosphatase was estimated according to Kielley (1954) at optimum pH 8.6 (tris buffer, 0.1 M). Analysis of 5'-nucleotidase was carried out at $\mathrm{pH} 9.5$ using $1.0 \mathrm{M}$-glycine buffer (Heppel \& Hilmoe, 1954) and glucose-6-phosphatase was assayed by the method of Swanson (1954) in citrate buffer at $\mathrm{pH} 6 \cdot 2$. The analyses of enzymes were performed in three to five replicates and the mean values after 7 and 15 days of irradiation for both the control and irradiated rats (five rats in each group) are reported in Table 1 .

The activity of acid $\beta$-glycerophosphatase in the testes continuously decreased after 72 -hr irradiation to values which were $82 \%$ of those of the control rats. On the 7 th day after irradiation, a $32 \%$ decrease in the activity of acid $\beta$ glycerophosphatase was recorded. On the 15 th day, this decrease was approxi- 


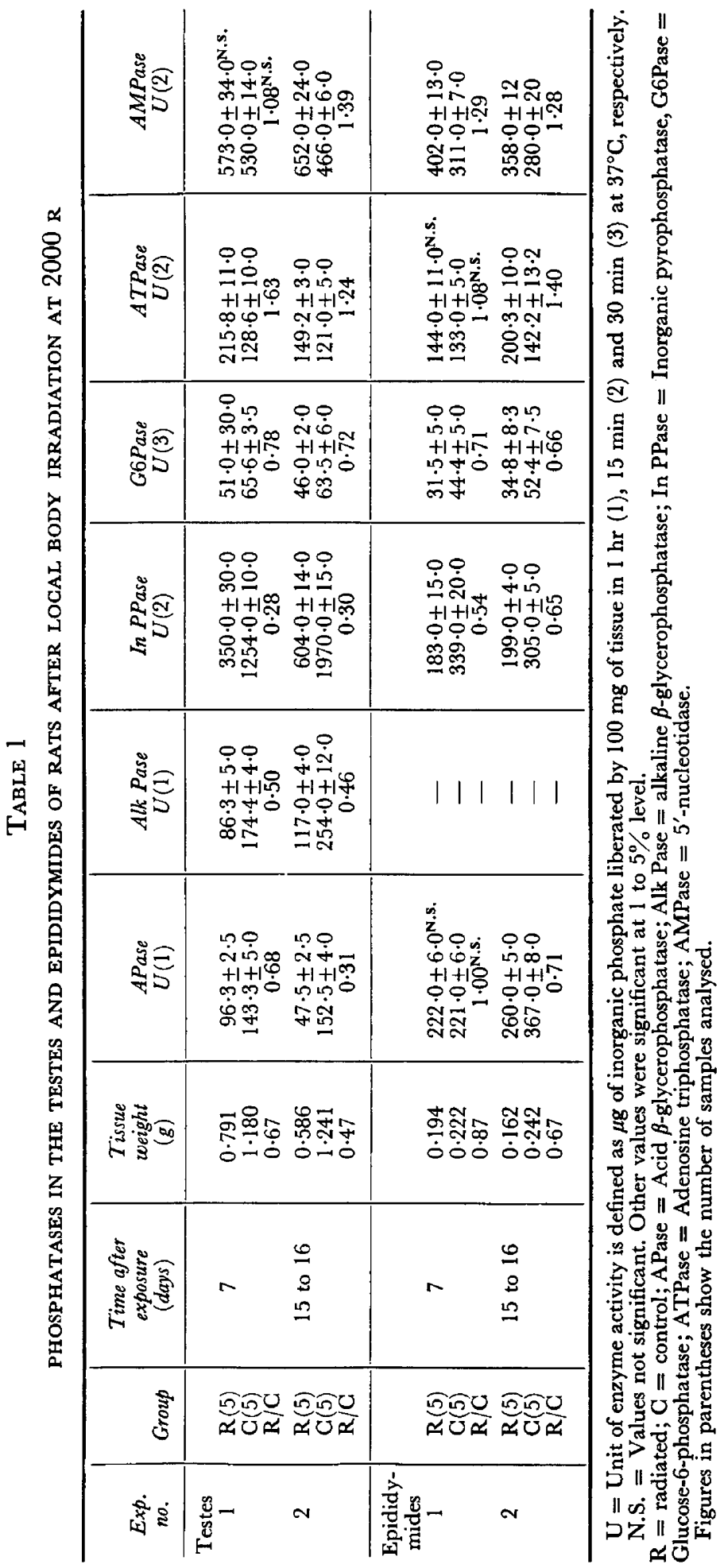


mately $70 \%$. In the epididymides, the loss in the activity of this enzyme was not appreciable in the early stages. Inorganic pyrophosphatase in the testes and epididymides seems to be more susceptible to radiation damage than acid $\beta$-glycerophosphatase and its activity after $24 \mathrm{hr}$ was $80 \%$ in the testes and $85 \%$ in the epididymides. After 7 days, its activity in the testes was $32 \%$ and in the epididymides was $54 \%$ that of the controls. Correspondingly, the level of inorganic pyrophosphate in the testes was ten times higher than in the normal animals. Similar but less pronounced effects were observed in the activity of alkaline phosphatase and glucose-6-phosphatase. Published reports suggest that inorganic pyrophosphatase and alkaline phosphatase represent the same protein with different sites of actions (Fleisch \& Russel, 1970). Specificities of microsomal glucose-6-phosphatase with inorganic pyrophosphatase of rat liver and kidney have also been described (Fleisch \& Russel, 1970). Similar overlapping of various phosphatases seem to occur in the testes and epididymides. Changes in several phosphatases and inorganic pyrophosphatase in the epidermis of guinea-pigs has been demonstrated after $\beta$-irradiation (Tabachnik, Perlish, Chang \& Freed, 1967). The rôle of inorganic pyrophosphatase in the regulatory mechanisms of biosynthetic processes has recently been reviewed (Fleisch \& Russel, 1970). It is highly probable that during cellular death after ionizing irradiation, synthetic activities may be reduced due to the accumulation of pyrophosphates. During this process, the reversal of reactions for nucleic acid biosyntheses may be most sensitive (Gupta \& Bawa, 1969, 1970). We believe that the loss of inorganic pyrophosphatase may be one of the initial events in cell injury due to ionizing radiation. The function of glucose-6phosphatase in carbohydrate metabolism is known and it is possible that the loss of this enzyme might be one of the factors responsible for the accumulation of glycogen in the tests (Gupta \& Bawa, unpublished observation). In human congenital Type-1 glycogen storage disease, it has been observed that this enzyme is almost lacking in both the liver and the kidney (Illingworth \& Cori, 1965). Besides the loss of the activities of several phosphatases, the present report suggests a low but consistent increase in the activity of 5 '-nucleotidase and adenosine triphosphatase. The increase in adenosine triphosphatase and 5'nucleotidase after irradiation has been described in several mammalian systems (Ord \& Stocken, 1961). It is possible that the loss of nucleotide precursors due to the increased activity of nucleotidases may be an additional event during the loss of nucleic acid biosyntheses after ionizing radiation. It is difficult to assess precisely the function of these enzymes because of the death of the germinal cells on the one hand and multiplication of interstitial and Sertoli cells on the other (Nebel \& Murphy, 1960; Ito, 1966; Kochar \& Bateman, 1969). It may, however, be concluded that the regulatory processes of the testes and epididymides are disturbed during irradiation, owing to loss of hydrolytic activities. Similar but less pronounced results have been observed at a sublethal dose of $720 \mathrm{R}$ (unpublished data).

The authors are grateful to Dr P. N. Chhuttani, Director, and Dr J. S. Sodhi, Associate Professor, of the Postgraduate Medical Institute, Chandigarh, for providing irradiation facilities. 


\section{REFERENCES}

Fleisch, H. \& Russed, R. G. G. (1970) Pyrophosphate and polyphosphate. In: Parathyroid Hormone, Thyrocalcitonin and Related Drugs, International Encyclopedia of Pharmacology and Therapeutics, Section 51, Vol. 1, p. 61. Ed. H. Rasmussen. Pergamon Press, Oxford.

Gupta, G. S. \& BAWA, S. R. (1969) Nucleic acids and oxidative enzymes in $X$-irradiated rat testis. Abstr. 3rd Int. Biophys. Congr., Int. Un. Pure Appl. Biophys, IV, 8; p. 137, Massachusetts, U.S.A.

Gupta, G. S. \& BAwA, S. R. (1970) Secretory activities of prostates and seminal vesicles after localized X-irradiation of rat testes. F. Reprod. Fert. 21, 329.

Heppel, L. A. \& Hicmoe, R. J. (1954) 5-Nucleotidase of seminal plasma. In: Methods in Enzymology, Vol. II, p. 546. Eds S. P. Colowick and N. O. Kaplan. Academic Press, New York.

Illingworth, B. \& Corr, G. F. (1965) Glucose-6-phosphatase and pyrophosphatase activities of homogenate of livers from patients with glycogen storage disease. Biochem. biophys. Res. Commun. 19,10 .

Iro, M. (1966) Histochemical observations of oxidative enzymes in irradiated testis and epididymis. Radiat. Res. 26, 266.

Kuelley, N. W. (1954) Mitochondrial ATPase. In: Methods in Enzymology, Vol. II, p. 583. Eds. S. P. Colowick and N. O. Kaplan. Academic Press, New York.

Kochar, N. K. \& Bateman, A. J. (1969) Post-irradiation changes in Sertoli cells. J. Reprod. Fert. $18,265$.

Nebel, B. R. \& Murphy, G. G. (1960) Damage and recovery of mouse testis after $1000 \mathrm{r}$ acute localised X-irradiation with reference to restitution cells, Sertoli cells increase and type A spermatogonia recovery. Radiat. Res. 12, 626.

Ord, M. G. \& Stocken, L. A. (1961) The biochemical lesion in vivo and in vitro. In: Mechanisms in Radiobiology, Vol. I, p. 259. Eds. M. Errera and A. Forssberg. Academic Press, New York.

Swanson, M. A. (1954) Glucose-6-phosphatase from liver. In: Methods in Enzymology, Vol. II, p. 541. Eds. S. P. Colowick and N. O. Kaplan. Academic Press, New York.

Tabachnik, J., Perisish, J. S., Ghang, L. F. \& Freed, R. M. (1967) Enzymatic changes in $\beta$ irradiated epidermis of guinea-pigs: acid and alkaline phosphatases and inorganic pyrophosphatase. Radiat. Res. 32, 293. 